\title{
Who Really Voted for Obama in 2008 and 2012?
}

\author{
Helena N. Hlavaty ${ }^{\mathrm{a}}$, Mohamed A. Hussein ${ }^{\mathrm{a}}$, Peter Kiley-Bergen ${ }^{\mathrm{a}}$, Liuxufei Yang ${ }^{\mathrm{a}}$, and Paul M. \\ Sommers ${ }^{\mathrm{a}}$
}

The authors use simple bilinear regression on statewide exit poll data to gauge the popularity of President Barack Obama in election years 2008 and 2012 among voters in four age groups (18 to 29 year-olds; 30 to 44 year-olds; 45 to 64 year-olds; and voters 65 or older) and three income groups (under $\$ 50,000 ; \$ 50,000$ to $\$ 100,000$; and voters earning more than $\$ 100,000$ ). While there was little change in his popularity among voters in all age groups, Obama's popularity with the poorest group of voters (earning less than \$50,000) took a noticeable hit in 2012.

Keywords: Regression; t-tests; presidential elections

Did President Barack Obama's popularity among different age and income groups change between 2008 and 2012? Exit poll data on four different age groups (18 to 29 years of age; 30 to $44 ; 45$ to 64 ; and 65 and over) as well as three different categories of family income (under $\$ 50,000$; between $\$ 50,000$ and $\$ 99,999$; and $\$ 100,000$ or more) were collected from Obama voters in both election years (www.cnn.com/ELECTION/2008/results/polls.main and www.cnn.com/election/2012/results/race/president\#exit_polls ). The purpose of this paper is to show how simple bilinear regression on these exit poll data in conjunction with the actual percentage of each state's Obama voters can be used to highlight Obama's relative attractiveness across age and income groups in the 2008 and 2012 presidential elections.

\section{Methodology}

Tables 1 and 2 show the results of statewide exit polls in 31 states in 2008 and for the same states in $2012 .^{1}$ Figure 1 shows a scatterplot of the actual percentage of Obama votes versus the percentage of Obama voters between 18 and 29 years of age, in both election years.

Each point represents a state whose actual percentage of Obama voters can be read along the vertical axis and percentage of Obama voters between 18 and 29 years of age (based on exit polls) can be read along the horizontal axis. ${ }^{2}$ What is the relationship between Obama's actual percentage of the total vote [Obama(actual)] and his support among voters under 30 years of age [Obama(18-29)], on average?
The estimated regression equation that summarizes this relationship would be given by:

$$
\operatorname{Obama}(\text { actual })=\mathrm{b}_{0}+\mathrm{b}_{1} \operatorname{Obama}(18-29)
$$

If, in all states, the percentage of Obama voters (18 to 29 years of age) were equal to the actual percentage of all voters who cast their ballots for Obama, then all points (in either panel of Figure 1) would fall on a 45-degree line, given by:

$$
\operatorname{Obama}(\text { actual })=\operatorname{Obama}(18-29)
$$

The regression equation and the 45-degree line intersect at a single point, where Obama(actual) is equal to Obama(18-29), hereafter called the critical point $\mathrm{x}^{*}{ }^{3}$, where

$$
x^{*}=\frac{b_{0}}{1-b_{1}} \text {. }
$$

If $x^{*}$ is, say, equal to 21.1 (as it is for 18-to-29 year-olds in the 2008 election), then the regression analysis predicts that, on average, in states where Obama received 21.1 percent or more of the state's total vote, he was more popular with 18-to-29 year-olds than he was with the state's general population. In fact, Barack Obama received no less than (Alabama's) 50 percent of the vote in any state in 2008 (see Table 1), a result that underscores his strong popularity among voters under 30 years of age. ${ }^{4}$ 
Table 1: President Barack Obama's Support in 2008 (percentage of vote)

\begin{tabular}{|c|c|c|c|c|c|c|c|c|}
\hline \multirow{3}{*}{ State } & \multirow{3}{*}{$\begin{array}{c}\text { Overall } \\
\text { Popular } \\
\text { Vote } \\
\text { (percent) }\end{array}$} & \multicolumn{7}{|c|}{ Exit Poll Results } \\
\hline & & \multicolumn{4}{|c|}{$\begin{array}{c}\text { Age } \\
\text { (years) }\end{array}$} & \multicolumn{3}{|c|}{$\begin{array}{c}\text { Income } \\
\text { (thousands of dollars) }\end{array}$} \\
\hline & & $18-29$ & $30-44$ & $45-64$ & $\geq 65$ & $<50$ & $50-100$ & $>100$ \\
\hline Alabama & 39 & 50 & 41 & 36 & 22 & 48 & 36 & 24 \\
\hline Arizona & 45 & 52 & 46 & 42 & 43 & 51 & 40 & 45 \\
\hline California & 61 & 76 & 59 & 60 & 48 & 66 & 61 & 57 \\
\hline Colorado & 54 & . & 53 & 56 & 44 & 57 & 51 & 56 \\
\hline Connecticut & 61 & 79 & 61 & 53 & . & 72 & 60 & 55 \\
\hline Florida & 51 & 61 & 49 & 52 & 45 & 62 & 44 & 44 \\
\hline Illinois & 62 & 71 & 66 & 54 & 55 & 74 & 55 & 54 \\
\hline Indiana & 50 & 63 & 47 & 49 & 37 & 56 & 46 & 45 \\
\hline Iowa & 54 & 61 & 48 & 54 & 49 & 61 & 50 & 46 \\
\hline Kansas & 42 & 51 & 37 & 44 & 34 & 48 & 39 & 37 \\
\hline Maine & 58 & 67 & 59 & 58 & 45 & 62 & 55 & 55 \\
\hline Maryland & 62 & 70 & 65 & 55 & . & 69 & 63 & 55 \\
\hline Massachusetts & 62 & 78 & 57 & 59 & . & 74 & 63 & 50 \\
\hline Michigan & 57 & 68 & 56 & 52 & 53 & 61 & 56 & 47 \\
\hline Minnesota & 54 & 65 & 49 & 51 & 55 & 59 & 53 & 49 \\
\hline Mississippi & 43 & 56 & 46 & 40 & . & 59 & 26 & 24 \\
\hline Missouri & 49 & 59 & 49 & 47 & 43 & 57 & 44 & 46 \\
\hline Montana & 47 & 61 & 36 & 47 & 45 & 56 & 41 & 42 \\
\hline Nevada & 55 & 67 & 60 & 51 & 42 & 64 & 54 & 49 \\
\hline New Hampshire & 54 & 61 & 51 & 56 & 56 & 59 & 53 & 56 \\
\hline New Jersey & 57 & 67 & 59 & 55 & 47 & 67 & 55 & 52 \\
\hline New Mexico & 57 & 71 & 52 & 54 & 53 & 65 & 52 & 53 \\
\hline New York & 63 & 76 & 61 & 59 & 55 & 73 & 61 & 56 \\
\hline North Carolina & 50 & 74 & 48 & 43 & 43 & 57 & 43 & 44 \\
\hline Ohio & 52 & 61 & 51 & 53 & 44 & 59 & 52 & 42 \\
\hline Oregon & 57 & . & 61 & 55 & 56 & 59 & 55 & 61 \\
\hline Pennsylvania & 55 & 65 & 51 & 55 & 49 & 62 & 52 & 52 \\
\hline Vermont & 68 & 81 & 60 & 68 & 69 & 70 & 67 & 66 \\
\hline Virginia & 53 & 60 & 51 & 51 & 46 & 62 & 52 & 46 \\
\hline Washington & 58 & . & 56 & 58 & 51 & 64 & 56 & 54 \\
\hline Wisconsin & 56 & 64 & 54 & 57 & 50 & 65 & 52 & 48 \\
\hline
\end{tabular}

Source: www.cnn.com/ELECTION/2008/results/polls.main 
Table 2: President Barack Obama's Support in 2012 (percentage of vote)

\begin{tabular}{|c|c|c|c|c|c|c|c|c|}
\hline \multirow{3}{*}{ State } & \multirow{3}{*}{$\begin{array}{c}\text { Overall } \\
\text { Popular } \\
\text { Vote } \\
\text { (percent) }\end{array}$} & \multicolumn{7}{|c|}{ Exit Poll Results } \\
\hline & & \multicolumn{4}{|c|}{$\begin{array}{c}\text { Age } \\
\text { (years) }\end{array}$} & \multicolumn{3}{|c|}{$\begin{array}{c}\text { Income } \\
\text { (thousands of dollars) }\end{array}$} \\
\hline & & $18-29$ & $30-44$ & $45-64$ & $\geq 65$ & $<50$ & $50-100$ & $>100$ \\
\hline Alabama & 38 & 48 & 44 & 35 & 31 & 45 & 30 & 30 \\
\hline Arizona & 44 & 63 & 37 & 38 & 29 & 47 & 41 & 43 \\
\hline California & 60 & 71 & 60 & 53 & 48 & 64 & 59 & 52 \\
\hline Colorado & 51 & . & 50 & 51 & 42 & 60 & 50 & 46 \\
\hline Connecticut & 58 & 66 & 55 & 58 & 54 & 73 & 54 & 53 \\
\hline Florida & 50 & 66 & 52 & 48 & 41 & 59 & 44 & 43 \\
\hline Illinois & 57 & 68 & 57 & 54 & 57 & 72 & 57 & 44 \\
\hline Indiana & 44 & 46 & 48 & 44 & 34 & 54 & 42 & 34 \\
\hline Iowa & 52 & 56 & 52 & 52 & 50 & 59 & 50 & 45 \\
\hline Kansas & 38 & 41 & 39 & 36 & 38 & 43 & 42 & 25 \\
\hline Maine & 56 & 63 & 56 & 57 & 55 & 59 & 54 & 57 \\
\hline Maryland & 62 & 70 & 64 & 56 & 64 & 79 & 61 & 51 \\
\hline Massachusetts & 61 & 73 & 56 & 59 & 56 & 70 & 58 & 54 \\
\hline Michigan & 54 & 63 & 56 & 51 & 48 & 62 & 49 & 48 \\
\hline Minnesota & 53 & 63 & 50 & 49 & 52 & 59 & 50 & 46 \\
\hline Mississippi & 44 & 55 & 44 & 45 & 22 & 54 & 30 & 23 \\
\hline Missouri & 44 & 58 & 42 & 44 & 33 & 52 & 39 & 38 \\
\hline Montana & 42 & 46 & 38 & 43 & 40 & 45 & 39 & 40 \\
\hline Nevada & 52 & 68 & 54 & 49 & 44 & 68 & 47 & 37 \\
\hline New Hampshire & 52 & 62 & 48 & 49 & 55 & 60 & 51 & 47 \\
\hline New Jersey & 58 & 63 & 59 & 60 & 48 & 63 & 55 & 61 \\
\hline New Mexico & 53 & 64 & 49 & 49 & 53 & 59 & 49 & 42 \\
\hline New York & 62 & 72 & 61 & 61 & 59 & 74 & 60 & 51 \\
\hline North Carolina & 48 & 67 & 51 & 47 & 35 & 55 & 45 & 44 \\
\hline Ohio & 51 & 63 & 51 & 47 & 44 & 59 & 47 & 40 \\
\hline Oregon & 54 & . & 51 & 52 & 53 & 59 & 45 & 64 \\
\hline Pennsylvania & 52 & 63 & 55 & 48 & 43 & 67 & 41 & 45 \\
\hline Vermont & 67 & 72 & 74 & 68 & 51 & 68 & 68 & 67 \\
\hline Virginia & 51 & 61 & 54 & 46 & 46 & 60 & 46 & 47 \\
\hline Washington & 56 & 66 & 60 & 50 & 51 & 64 & 49 & 59 \\
\hline Wisconsin & 53 & 60 & 51 & 51 & 48 & 62 & 49 & 39 \\
\hline
\end{tabular}

Source: www.cnn.com/election/2012/results/race/president 

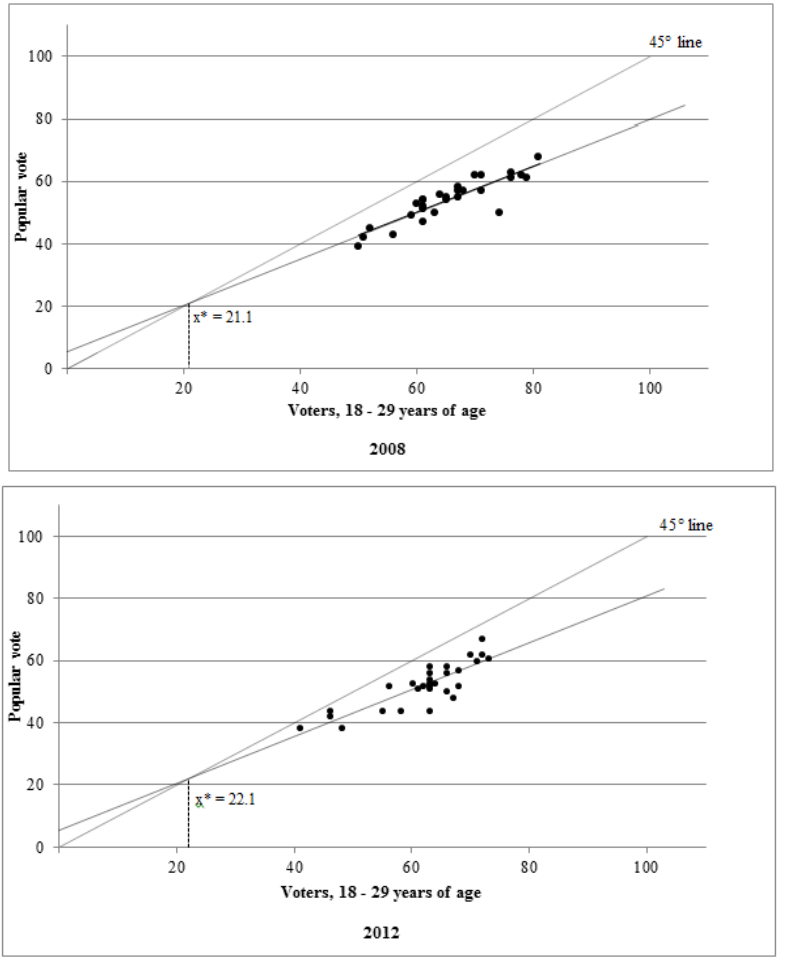

Figure 1: Exit poll results, voters 18 to 29 years of age, by election year

\section{Results}

Table 3 summarizes the regression results for all four demographic and three income groups in both 2008 and 2012. Scatterplots appear in Figures 1 through 7 . The last column of Table 3 gives the critical points of intersection between the regression line and a 45-degree line. ${ }^{5}$ Obama was most popular with 18-to-29 year-olds and voters with incomes under $\$ 50,000$. The critical value of only 4.5 in the last column of Table 3 for Obama voters in 2008 with incomes under $\$ 50,000$ shows how very popular he was with the poorest voters. Obama was least popular with voters over 44 years of age and voters with family incomes of at least $\$ 50,000$ in both election years. Among voters 65 years of age or older, he was more popular than the general electorate (i.e., his actual vote percentage exceeded 64.7 percent in 2008 and 61.0 percent in 2012) in just one state in 2008 (Vermont) and one state in 2012 (Maryland). Among voters from families earning more than $\$ 100,000$ a year, he was more popular than the general electorate (i.e., his actual vote percentage exceeded 64.4 percent in 2008 and 60.2 percent in 2012) in just one state in 2008 (Vermont) and in only three states in 2012 (New Jersey, Oregon and Vermont).

The most interesting result in Table 3 is the much higher critical point for 2012 voters from families with incomes under $\$ 50,000\left(\mathrm{x}^{*}=31.1\right.$ in 2012 compared with $\mathrm{x}^{*}=4.5$ in 2008). The precipitous drop in Obama's popularity among the poorest voters might reflect their dissatisfaction with first term policies that failed to insulate them from the worst effects of the Great Recession. The poor were no better off in 2012 than they were when President Obama took office in $2008 .^{6}$ And, judging from poverty rates in the years leading up to the 2012 election, the poorest voters were much worse off. $^{7}$ 
Table 3: Summary of Regression Results, 2008 and 2012

\begin{tabular}{|c|c|c|c|c|}
\hline Variable & $\begin{array}{c}\text { Constant } \\
\left(b_{0}\right)\end{array}$ & $\begin{array}{c}\text { Slope } \\
\left(\mathbf{b}_{1}\right)\end{array}$ & $\mathbf{R}^{2}$ & Critical Point, $x^{*}$ \\
\hline \multicolumn{5}{|c|}{2008} \\
\hline \multicolumn{5}{|l|}{$\begin{array}{c}\text { Age } \\
\text { (years) }\end{array}$} \\
\hline $18-29$ & $\begin{array}{l}5.4087 \\
(1.10)^{1} \\
\end{array}$ & $\begin{array}{l}0.7442 \\
(9.99)^{2}\end{array}$ & 0.797 & 21.1 \\
\hline $30-44$ & $\begin{array}{c}13.3854 \\
(3.12) \\
\end{array}$ & $\begin{array}{l}0.7755 \\
(9.66) \\
\end{array}$ & 0.763 & 59.6 \\
\hline $45-64$ & $\begin{array}{l}6.3946 \\
(1.53) \\
\end{array}$ & $\begin{array}{l}0.9161 \\
(11.55)\end{array}$ & 0.822 & 76.2 \\
\hline$\geq 65$ & $\begin{array}{c}24.7951 \\
(6.58) \\
\end{array}$ & $\begin{array}{l}0.6165 \\
(7.87) \\
\end{array}$ & 0.713 & 64.7 \\
\hline \multicolumn{5}{|c|}{$\begin{array}{c}\text { Income } \\
\text { (thousands of dollars) }\end{array}$} \\
\hline$<50$ & $\begin{array}{l}0.5825 \\
(0.11) \\
\end{array}$ & $\begin{array}{l}0.8696 \\
(10.61) \\
\end{array}$ & 0.795 & 4.5 \\
\hline $50-100$ & $\begin{array}{c}18.1900 \\
(7.59) \\
\end{array}$ & $\begin{array}{l}0.7071 \\
(15.31) \\
\end{array}$ & 0.890 & 62.1 \\
\hline$>100$ & $\begin{array}{c}23.3200 \\
(6.85) \\
\end{array}$ & $\begin{array}{c}0.6378 \\
(9.28) \\
\end{array}$ & 0.748 & 64.4 \\
\hline \multicolumn{5}{|c|}{2012} \\
\hline \multicolumn{5}{|l|}{$\begin{array}{c}\text { Age } \\
\text { (years) }\end{array}$} \\
\hline $18-29$ & $\begin{array}{l}5.4520 \\
(0.97)\end{array}$ & $\begin{array}{l}0.7534 \\
(8.38)\end{array}$ & 0.722 & 22.1 \\
\hline $30-44$ & $\begin{array}{l}9.7547 \\
(2.68)\end{array}$ & $\begin{array}{l}0.8125 \\
(11.78) \\
\end{array}$ & 0.827 & 52.0 \\
\hline $45-64$ & $\begin{array}{l}6.3705 \\
(2.09) \\
\end{array}$ & $\begin{array}{l}0.9158 \\
(15.20) \\
\end{array}$ & 0.885 & 75.7 \\
\hline$\geq 65$ & $\begin{array}{c}25.2054 \\
(6.87)\end{array}$ & $\begin{array}{l}0.5868 \\
(7.51)\end{array}$ & 0.660 & 61.0 \\
\hline \multicolumn{5}{|c|}{$\begin{array}{c}\text { Income } \\
\text { (thousands of dollars) }\end{array}$} \\
\hline$<50$ & $\begin{array}{l}8.8108 \\
(2.08)\end{array}$ & $\begin{array}{l}0.7171 \\
(10.36)\end{array}$ & 0.787 & 31.1 \\
\hline $50-100$ & $\begin{array}{r}15.5743 \\
(5.16) \\
\end{array}$ & $\begin{array}{l}0.7556 \\
(12.30) \\
\end{array}$ & 0.839 & 63.7 \\
\hline$>100$ & $\begin{array}{c}26.9096 \\
(7.70) \\
\end{array}$ & $\begin{array}{l}0.5532 \\
(7.40) \\
\end{array}$ & 0.654 & 60.2 \\
\hline
\end{tabular}

${ }^{1}$ Numbers in parentheses are t-values.

${ }^{2}$ All slope coefficients are significant at better than the 0.001 level. 

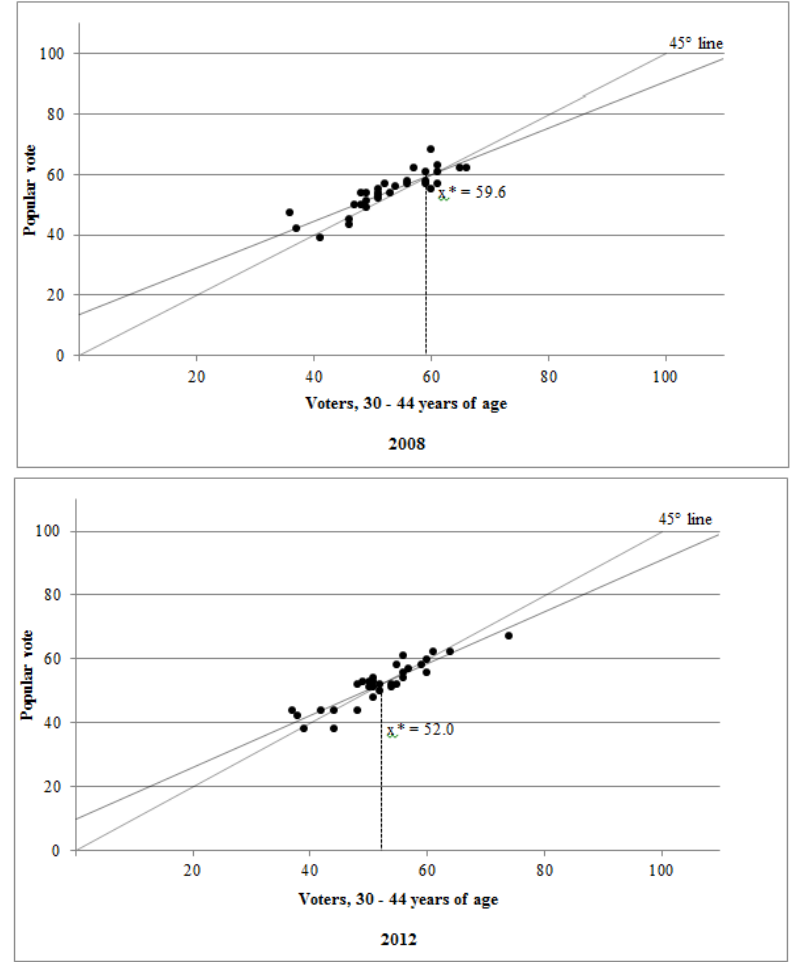

Figure 2: Exit poll results, voters 30 to 44 years of age, by election year
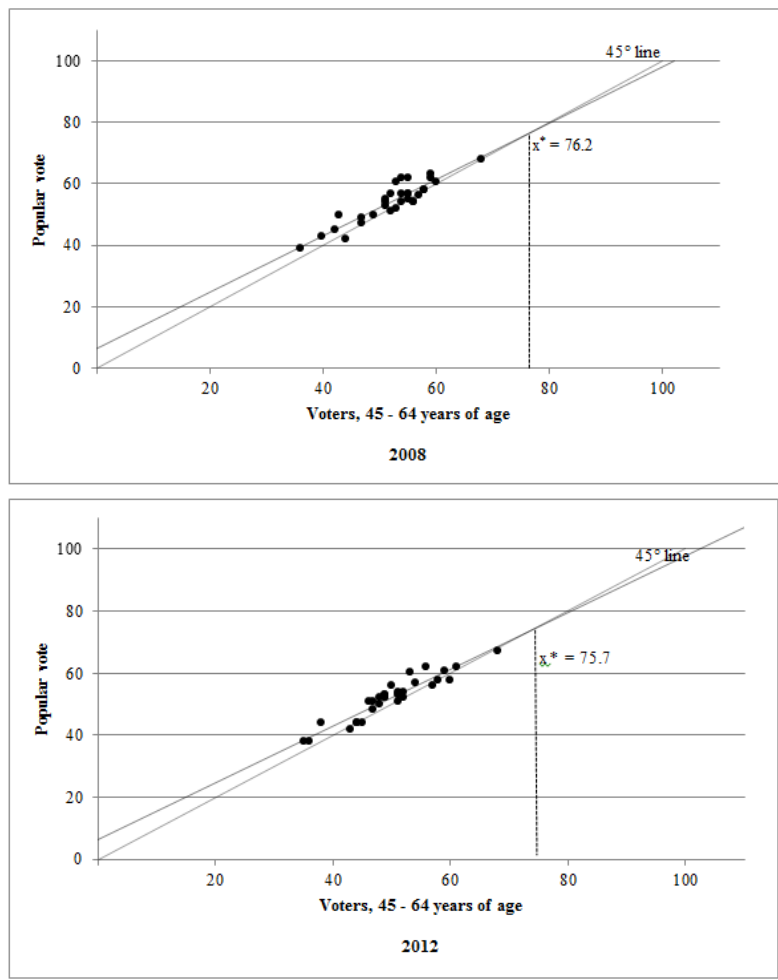

Figure 3: Exit poll results, voters 45 to 64 years of age, by election year
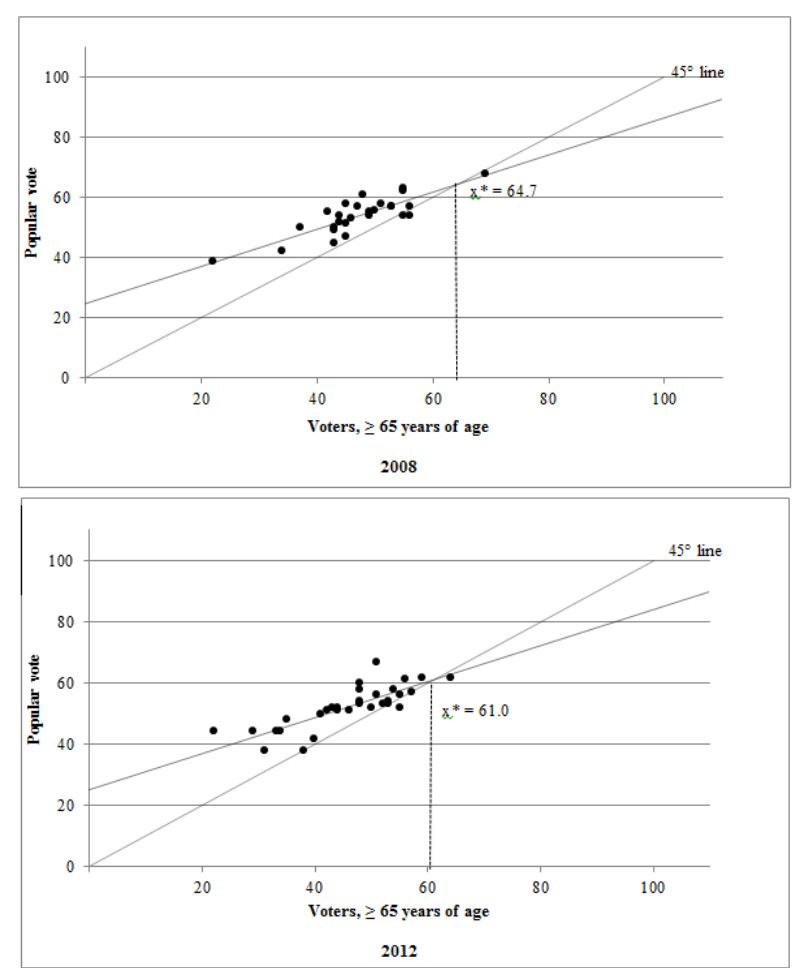

Figure 4: Exit poll results, voters 65 years of age and older, by election year
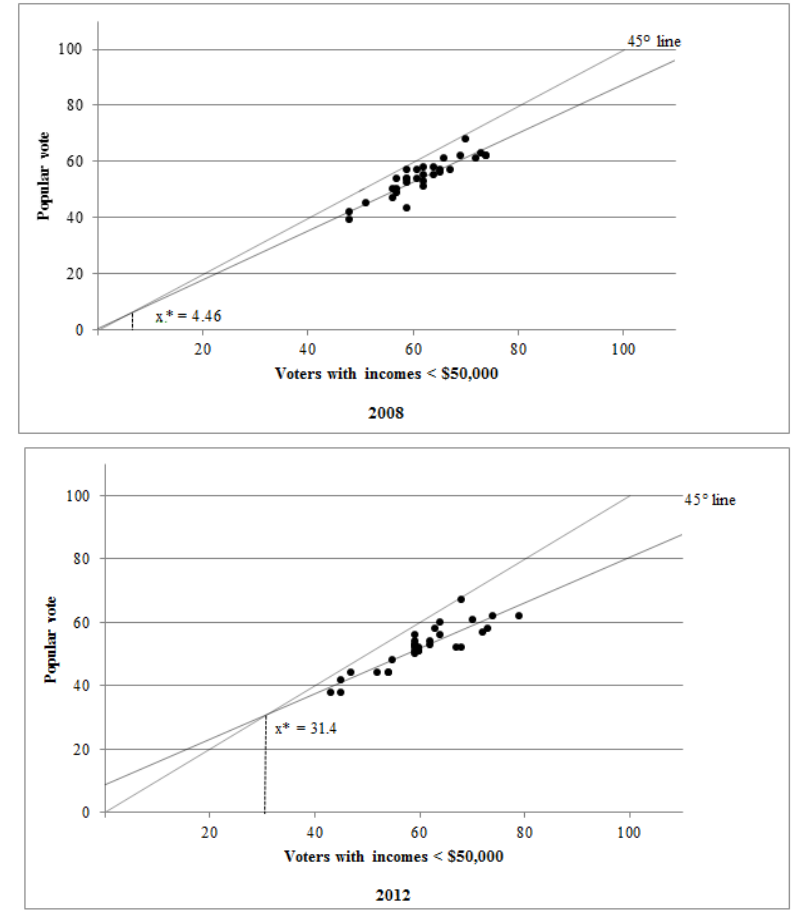

Figure 5: Exit poll results, voters with incomes less than $\$ 50,000$, by election year 

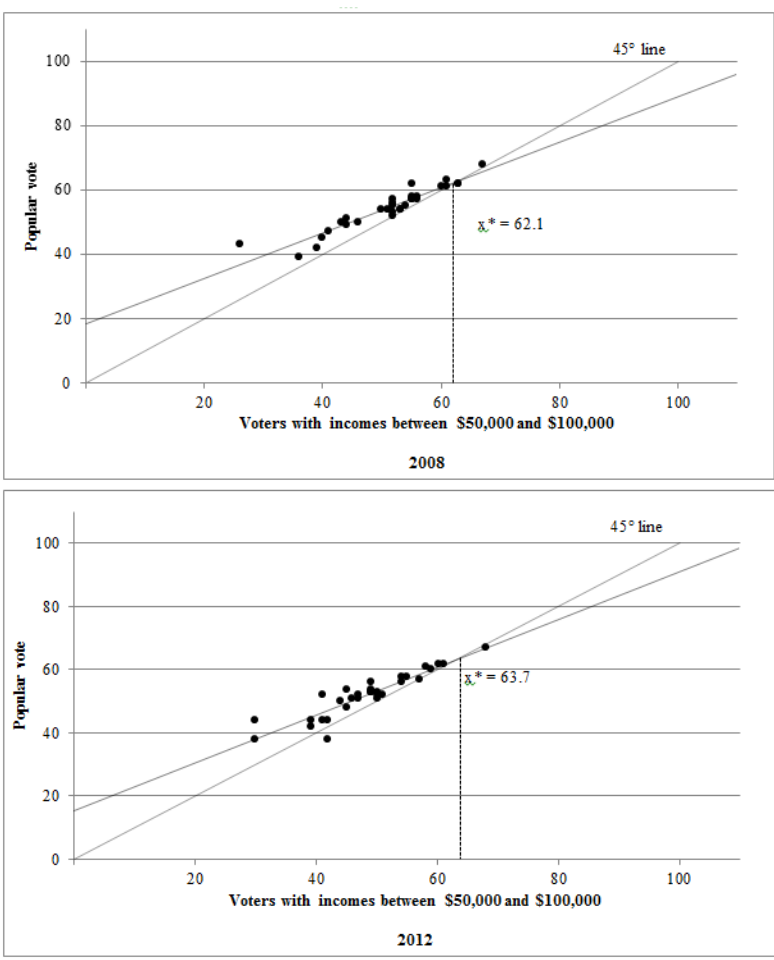

Figure 6: Exit poll results, voters with incomes between $\$ 50,000$ and $\$ 100,000$, by election year
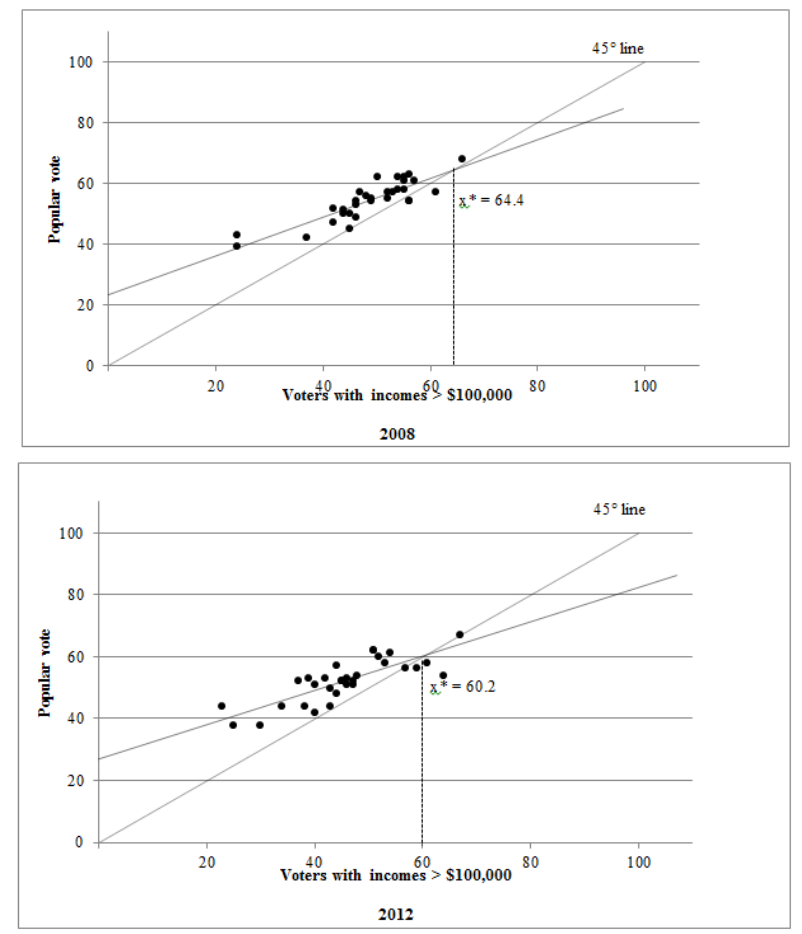

Figure 7: Exit poll results, voters with incomes greater than $\$ 100,000$, by election year

\section{Concluding Remarks}

Regression analysis on election exit poll data can be used to gauge a candidate's relative popularity among different demographic and socioeconomic groups.

In 2008, the youngest and poorest voters played a decisive role in electing the first-ever African-American U.S. President. For voters over 44 years of age and voters from families earning more than $\$ 50,000$, Obama's support was no greater than (and, in some instances, substantially less than) his support from all voters. And, in 2012, although Obama enjoyed continued strong support from the youngest group of voters, his popularity among the poorest voters clearly had waned.

\section{References}

1. A. A. Chong, M. B. Ralston, A. C. Waxman, and P. M. Sommers, Who really voted for Barack Obama?, Journal of Recreational Mathematics, vol. 35(2), 128-131, 2009.

2. 2008 election exit poll results: www.cnn.com/ELECTION/2008/results/polls.main .

3. 2012 election exit poll results: www.cnn.com/election/2012/results/race/president\#.

4. United States Census Bureau. (2013 September). Poverty: 2000 to 2012.Retrieved from

www.census.gov/library/publications/2013/acs/acsbr12$\underline{01 . h t m l}$. 


\section{Footnotes}

1. In 2012, CNN did not (unlike four years earlier) report the detailed results of a statewide exit poll in each of the 50 states. Edison Research, the exclusive provider of the National Election Exit Polls to major U.S. television news networks, including $\mathrm{CNN}$, conducted a detailed statewide exit poll (by age group and income group) in just 31 of the states in 2012. These same 31 states are examined in this paper four years earlier.

2. In 2008, CNN did not report the breakdown between Obama and John McCain, his Republican opponent, for 1829 year-olds in the states of Colorado, Oregon and Washington. (In 2012, there was again no exit poll data on 18-29 year-olds in the states of Colorado and Oregon.) There were observations on all 31 states for 30-44 and 4564 year-olds. Among voters 65 years of age and over there were missing observations in 2008 on Obama for Connecticut, Maryland, Massachusetts and Mississippi, but no missing observations for this age group in 2012. Insofar as the three income groups were concerned, the exit poll data on Obama voters was complete for all 31 states both years.

3. Setting equation (1) equal to equation (2) and solving for Obama(18-29), that is, the point of intersection between the regression line and the 45 -degree line yields a critical value for Obama(18-29) equal to $b_{0} / 1-b_{1}$, hereafter $x^{*}$. An analysis of all 50 states in 2008 appears in Chong et al. (2009).

4. Figure 1 shows that in all 28 states, Obama's percentage of the vote among those under 30 years of age exceeded his percentage of the actual vote among all voters, that is, all observations lie below the 45-degree line.

5. A series of paired $t$-tests across the 31 states between Obama's actual percentage of the state's total vote and the state's corresponding Obama support in 2008 [2012] for each of the four age groups was significant for 18-29 yearolds ( $p<.001$ [ $p<.001]$, in Obama's favor); significant for 30-44 year-olds in 2008, but not significant in 2012

( $p=.028$ in John McCain's favor [ $p=.957])$; significant for 45-64 year-olds $(p<.001$, in McCain's favor [ $p<.001$, in Mitt Romney's favor]); and significant for voters 65 years of age or older $(p<.001$, again in McCain's favor [ $p$ $<.001$, again in Romney's favor]). All three paired $t$-tests involving income groups were statistically significant $(p<.001[p<.001])$, with only the poorest income group (i.e., families earning less than $\$ 50,000$ ) favoring Obama in 2008 and again in 2012.

6. According to the U.S. Census Bureau (2013), the poverty rates in the four years prior to the 2012 election were 13.2 percent (2008), 14.3 percent (2009), 15.3 percent (2010), and 15.9 percent (2011).
7. A paired $t$-test involving all three income groups between 2008 and 2012 showed that Obama lost support among voters in the poorest income group $(p=.047)$, as well as among voters with incomes $\$ 50,000$ to $\$ 100,000(p<.001)$ and voters with incomes greater than $\$ 100,000(p<.01)$. 